\title{
Research-oriented ground investigation projects at Changi, Singapore
}

Myint Win Bo PhD, PEng, PGeo, IntPE, CEng, CGeol, CSci, CEnv, CMgr, FICE, FGS

President and Chief Executive Officer, Bo \& Associates Ltd, Milton, ON, Canada (corresponding author: mwinbo@boandassociates.net)

Arul Arulrajah PhD, MEng, CPEng, FIEAus

Professor, Swinburne University of Technology, Melbourne, Australia

Victor Choa PhD, MA

Professorial Fellow, Nanyang Technological University, Singapore
Suksun Horpibulsuk PhD, MEng

Professor, School of Civil Engineering, Suranaree University of Technology, Nakhon Ratchasima, Thailand; Director, Center of Excellence in Innovation for Sustainable Infrastructure Development, Suranaree University of Technology, Nakhon Ratchasima, Thailand

Wisanukorn Samingthong MEng

Post-graduate Researcher, Center of Excellence in Innovation for

Sustainable Infrastructure Development, Suranaree University of

Technology, Nakhon Ratchasima, Thailand

The Changi East Reclamation projects in Singapore were implemented in five phases starting from 1991 and completed in 2005. Due to the excessive magnitude of settlement likely to occur over a long period of duration caused by the consolidation process, an extensively large area was required to be improved using ground improvement techniques to accelerate the consolidation process. The planning and implementation of site investigation works for land reclamation projects is discussed in this paper. An accurate and extensive geotechnical characterisation of underlying soft compressible marine clay was undertaken as part of this project. The geotechnical characterisation was undertaken using site investigation, specialised laboratory testing and specialised in situ testing. Correlations were obtained using empirical methods, which will be useful for future use such as correlations between classification parameters as well as specialised in situ test parameters and strength and compressibility parameters of Singapore marine clay at Changi, Singapore. This paper presents how the research-oriented ground investigation projects were implemented for this mega land reclamation project in the Republic of Singapore.

\section{Notation}

$B_{\mathrm{q}} \quad$ pore pressure parameter

$C_{\mathrm{c}} \quad$ compression index

$C_{\mathrm{h}} \quad$ coefficient of consolidation due to horizontal flow

$C_{\mathrm{r}} \quad$ compression index

$e_{0} \quad$ natural void ratio

$G \quad$ shear modulus

$h, k \quad$ coefficient of constant

$K_{0} \quad$ earth pressure coefficient at rest

$K_{\text {Onc }} \quad$ earth pressure coefficient at rest for normally consolidated soil

$K_{\text {Oос }}$ earth pressure coefficient at rest for overconsolidated soil

$K_{\mathrm{D}} \quad$ lateral stress index

$L_{\mathrm{L}} \quad$ liquid limit

$M \quad 6 \sin \phi^{\prime} /\left(3-\sin \phi^{\prime}\right)$

$N_{\text {kt }} \quad$ cone factor

$N_{\mathrm{p}} \quad$ pressuremeter constant

$N_{\text {RST }}$ blow count for ram sounding test

$N_{\text {SPT }}$ blow count for standard penetration test

OCR overconsolidation ratio

$P_{\mathrm{I}} \quad$ plastic index

$P_{\mathrm{L}} \quad$ limit pressure

$q_{\mathrm{t}} \quad$ cone tip resistance

$s_{\mathrm{u}} \quad$ undrained shear strength

$u_{\mathrm{bt}} \quad$ pore pressure at the base of cone tip

$W \quad$ moisture content

$\Lambda \quad$ coefficient of constant with value of 0.75

$\alpha \quad$ constant with a value of 0.32 $\theta \quad$ diffraction angle

$\sigma_{\text {ho }} \quad$ in situ total horizontal stress

$\sigma_{\mathrm{v}}^{\prime} \quad$ effective overburden stress

$\sigma_{\mathrm{vo}} \quad$ total overburden stress

$\sigma_{\mathrm{vo}}^{\prime} \quad$ effective vertical stress

\section{Introduction}

The Changi East Reclamation projects in Singapore were implemented in five phases starting from 1991 and completed in 2005. Each of these overlapping phases lasted for up to 5 years. The total implementation period was 15 years including the maintenance period. The phases were named as phases $1 \mathrm{~A}, 1 \mathrm{~B}$ and $1 \mathrm{C}$ and area $\mathrm{A}$ (north) and area A (south). The project area is shown in Figure 1. Details of phases are given in Table 1. Due to the involvement of large area fill in the form of land reclamation with up to $20 \mathrm{~m}$ thick hydraulic fills over $40 \mathrm{~m}$ thick compressible marine clay, significant challenges were posed to the geotechnical engineers on issues such as slope stability, consolidation settlement and liquefaction potential.

Due to the excessive magnitude of settlement likely to occur over a long period of duration caused by the consolidation process, an extensively large area was required to be improved using ground improvement techniques to accelerate the consolidation process. Therefore, an accurate and extensive geotechnical characterisation of underlying soft compressible marine clay was deemed necessary. In addition to the improvement of the underlying soils, improvement was also required for the land reclamation fills that were loosely deposited by means of hydraulic filling techniques. In addition, as the land reclamation was carried out at the 
Geotechnical Research

Volume 4 Issue GR1
Research-oriented ground investigation

projects at Changi, Singapore

Bo, Arulrajah, Choa, Horpibulsuk and Samingthong

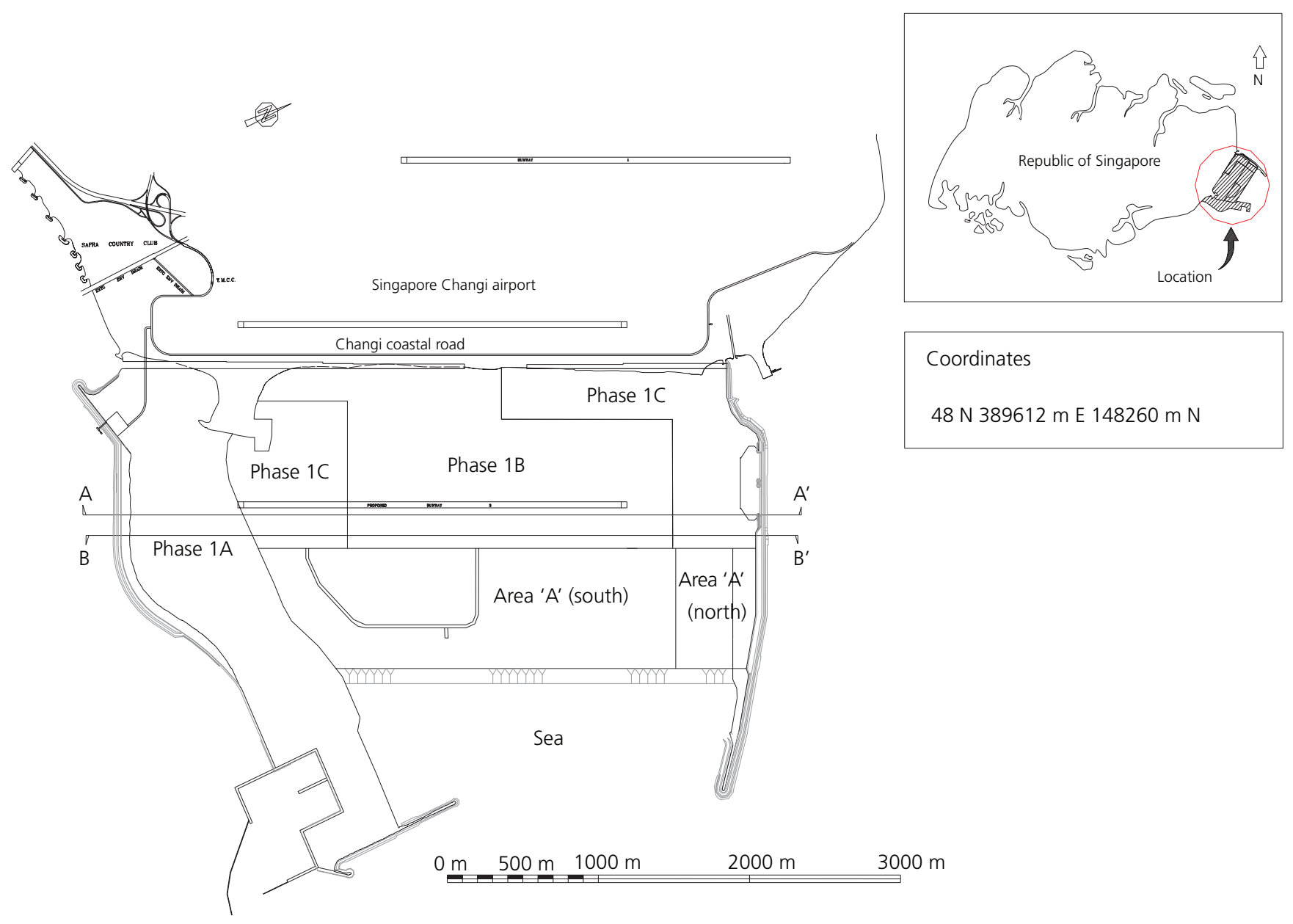

Figure 1. Location of the Changi East Reclamation projects (Chu et al., 2009)

foreshore areas, boundaries and edges of land reclamation were required to be retained and protected by suitable forms of shoreprotection structures. These shore-protection structures were required for short- and long-term stability designs.

In order to be able to implement these complex projects successfully, using the latest state-of-the-art technologies, the implementation of research-level planning, investigation and implementation processes was required throughout the projects from the master planning to the commissioning stages. Several kinds of quality control and quality assurance and several pilot tests were implemented. This paper presents how the research-oriented ground investigation at Changi East Reclamation and Ground Improvement projects was implemented in the last decade in the Republic of Singapore.

Table 1. Details of the Changi East Reclamation projects

\begin{tabular}{|c|c|c|c|c|c|c|}
\hline & Phase 1A & Phase 1B & Phase $1 \mathrm{C}$ & $\begin{array}{l}\text { Area A } \\
\text { (north) }\end{array}$ & Area A (south) & Total \\
\hline Area: ha & 501 & 520 & 451 & $90 \cdot 7$ & 450 & $2012 \cdot 7$ \\
\hline Area improved with PVD: ha & - & 224 & 400 & $90 \cdot 7$ & $50 \cdot 4$ & $765 \cdot 1$ \\
\hline $\begin{array}{l}\text { Area improved with deep } \\
\text { compaction: ha }\end{array}$ & - & 114 & 77 & - & - & 191 \\
\hline Shore protection: $\mathrm{m}$ & 5141 & - & 5185 & - & - & 10326 \\
\hline Sheet pile wall: m & 3789 & - & - & - & - & 3789 \\
\hline \multirow[t]{2}{*}{ Project duration } & January & March & March & March & February & January \\
\hline & $\begin{array}{c}\text { 1992-January } \\
1997\end{array}$ & $\begin{array}{c}\text { 1993-September } \\
1999\end{array}$ & $\begin{array}{l}\text { 1996-September } \\
2002\end{array}$ & $\begin{array}{c}\text { 1999-March } \\
2004\end{array}$ & $\begin{array}{l}\text { 1999-February } \\
2005\end{array}$ & $\begin{array}{c}\text { 1992-February } \\
2005\end{array}$ \\
\hline
\end{tabular}

PVD, prefabricated vertical drain 


\section{Planning stage}

The need for an airport with a $4 \cdot 2 \mathrm{~km}$ runway and associated taxiways situated outside of the residential areas of Singapore was due to concern about environmental noise pollution. At the same time, limited land space in Singapore, as in other Asian countries such as Japan, Hong Kong, Macao and Taiwan, required land reclamation to be undertaken. The construction of land reclamation in the foreshore area, which is underlain by compressible soft marine clay, required a large quantity of fill material, including average volume loss due to settlement of more than $2 \mathrm{~m}$ due to the consolidation settlement and densification of granular fills. A large quantity of rock fill was also required for approximately $14 \mathrm{~km}$ long shore-protection works. The entire project was planned to be carried out over a 15-year duration under five phases to create 3000 ha of land. The project required 272 million $\mathrm{m}^{3}$ of sand, $2 \cdot 12$ million $\mathrm{m}^{3}$ of rock, 141 million linear $\mathrm{m}$ of prefabricated vertical drains (PVDs), 2.7 million $\mathrm{m}^{2}$ of geotextiles and $14000 \mathrm{t}$ of steel for shore-protection works. The details of the construction materials used in each phase of the Changi East Reclamation projects are given in Table 2.

\section{Preliminary investigation}

Preliminary investigations were carried out as early as the late 1980s, and specifications for detail investigation during the project implementation were planned and included in each phase of the project. In each phase of the project, provision of drilling rigs, jack-up pontoons for foreshore soil investigation, geophysical surveys, hydrographic surveys and specialised in situ testing and equipment were included in the project specifications. The establishment of a soil laboratory and a quality control laboratory for PVD and geotextiles was also included in the specifications.

\section{Detail investigation}

Detail design investigations were usually carried out a couple of years prior to the call for tender for each phase. Except for detail site investigation for phase $1 \mathrm{~A}$, all other site investigations for other phases were carried out during the implementation of the prior phase. The detail design site investigation involved the following tasks

- hydrographic survey at and surrounding the land reclamation area

- topographic survey adjacent to the land reclamation area

- geophysical survey at and surrounding the land reclamation area

- geotechnical investigation at and surrounding the land reclamation area.

\section{Hydrographic and geophysical surveys}

Marine bathymetric surveys, together with marine geophysical seismic reflection surveys of the project areas, were carried out using echo sounder equipment with the help of a water-surfacetowed system, running along the specified parallel lines with a specified spacing. The locations of the sounding points were identified with differential global positioning systems. Elevations of the seabed were interpreted from the hydrographic survey, which produced seabed elevation contour and spot level maps. The required net volumes of sand fill were calculated using hydrographic survey data.

The elevations of the top and base and the thicknesses of the compressible layers and the distribution and dimensions of soft marine clay pockets deposited in submarine valley cuts were determined from marine hydrographic and seismic reflection surveys. The seismic survey vessel was fitted with a trisponder, an echo sounder and a boomer profiling system. The survey operation was run at lines with a spacing of $50 \mathrm{~m}$ in alternate directions. Cross-lines were run at a spacing of $50 \mathrm{~m}$ in alternate directions. For the horizontal control of the survey, a trisponder positioning system was used to control the location of the survey vessel along the precomputed lines. For the vertical control of the survey, the tidal reduction of the survey area was carried out using tides observed with a tide gauge. Tidal data were obtained from the Hydrographical Department of the Port of Singapore.

The echo sounder enabled the contouring of the seabed elevation profile, while the boomer enabled the plotting of the isolines of the base elevation of the marine clay deposit. A description of the geological sequence was then obtained based on the interpretation of the boomer data, and this could be correlated with the marine borehole data provided over the survey area. Figure 2 shows typical isolines and presents the total thickness of marine clay in the study area.

\section{Geotechnical investigation}

Site investigations were carried out prior to reclamation to profile the underlying geological formation and to characterise the geotechnical properties of the underlying soils.

\section{Boring and sampling}

Offshore site investigation boreholes were carried out to profile the formation and to collect samples for further laboratory tests for geotechnical characterisation. Borehole locations were identified based on the approximate profile interpreted from the

Table 2. Details of construction materials used in the Changi East Reclamation projects

\begin{tabular}{|c|c|c|c|c|c|c|}
\hline & Phase 1A & Phase 1B & Phase 1C & Area A (north) & Area A (south) & Total \\
\hline Sand: million $\mathrm{m}^{3}$ & 65 & 75 & 68 & 12 & 52 & 272 \\
\hline Rock: million $\mathrm{m}^{3}$ & 1 & - & 1.03 & 0.09 & - & $2 \cdot 12$ \\
\hline PVD: linear $m$ & - & 28 & 49 & $13 \cdot 3$ & $50 \cdot 4$ & $140 \cdot 7$ \\
\hline Geofabric: million $\mathrm{m}^{2}$ & 0.5 & - & 0.4 & 0.075 & - & 0.975 \\
\hline Steel: $\mathrm{t}$ & 14000 & - & - & - & - & - \\
\hline
\end{tabular}




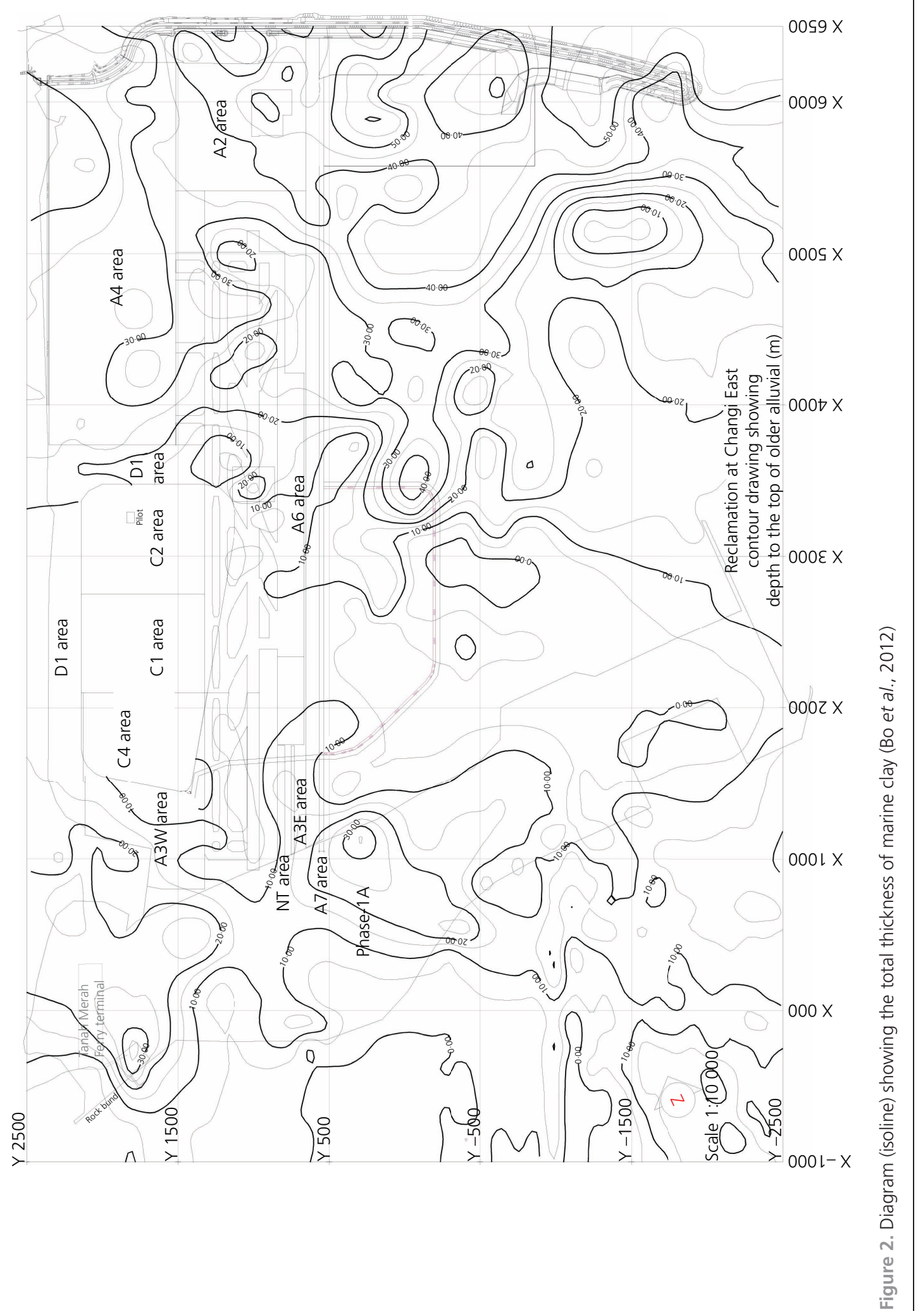


geophysical survey. Site investigations at the foreshore location were usually carried out from a jack-up pontoon.

Usually, continuous undisturbed sampling with either a piston sampler or thin-wall sampler was carried out. The choice of sampler was made depending on the consistency of the clay encountered. Samples of soft clay (less than $25 \mathrm{kPa}$ ) were taken with either a 75 or a $100 \mathrm{~mm}$ dia. piston sampler, whereas firm clay samples (between 25 and $50 \mathrm{kPa}$ ) were taken with a $100 \mathrm{~mm}$ dia. Shelby tube thin-wall sampler. Samples of stiff-to-hard clay (greater than $50 \mathrm{kPa}$ ) were taken with a thick-wall drive sampler. Collected sample tubes were sealed straight away with a mixture of wax and Vaseline on-site and sent to the on-site laboratory with great care during transportation. If there was soft clay or firm clay, field vane shear tests (FVTs) were carried out adjacent to the borehole to measure the in situ undrained shear strength of the clay.

Termination criteria of boreholes were generally set as achieving three consecutive standard penetration test (SPT) blow counts of 50. The SPT was used only for the determination of termination criteria in accordance with the specification requirement stated above and was not used for any characterisation purpose.

Details of the site investigation works for Changi East Reclamation projects can also be found in the studies by Bo et al. (1998a, 1998b, 2000, 2003, 2012) and Arulrajah et al. (2004b, 2006a, 2006b). Table 3 gives the numbers of boreholes and conventional in situ tests carried out for the various phases of the projects.

\section{Specialised in situ testing}

As the project being carried out has major geotechnical challenges, many advanced geotechnical parameters, such as the coefficient of consolidation due to horizontal flow, modulus of elasticity, overconsolidation ratio (OCR), shear wave velocities and so on, were required for geotechnical analyses and modelling. Therefore, the following kinds of specialised geotechnical in situ tests were carried out in each project phase both prior to land reclamation and during and after soil improvement

- cone penetration tests with pore pressure measurements (CPTUs)

- dilatometer tests (DMTs)
- self-boring pressuremeter tests (SBPMTs)

- Bengt-Arne Torstensson permeameter tests (Bats)

- seismic cone tests (SCTs)

- cone pressuremeter tests (CPMTs)

- gamma-gamma probing

- plate load tests (PLTs)

- screw plate tests (SPLTs)

ram sounding tests (RSTs).

Many of the specialised in situ tests were carried out side-byside with conventional in situ tests and standard boring and sampling; many site-specific empirical correlations required for geotechnical parameter interpretations were developed during the site investigation.

The type of tests carried out, measured parameters and interpreted parameters obtained are given in Table 4. Details of each type of in situ test are briefly described below.

\section{CONE PENETRATION TESTS WITH PORE PRESSURE MEASUREMENTS}

Extensive numbers of CPTUs were carried out for site characterisation purposes, stratigraphic profiling purposes and compaction quality control purposes. Cone resistances and side frictions were measured, and those parameters were used for the classification and interpretation of geotechnical parameters. CPTUs were also used, not only for the determination of clay thicknesses and PVD installation depths but also for the measurement of the settlement after ground improvement. Various applications of CPTU in these projects are described in detail by Bo et al. (2001). The number of cone penetration tests (CPTs) carried out in Changi East Reclamation and Ground Improvement projects is given in Table 5 .

\section{DILATOMETER TESTS}

DMTs were also carried out prior to the improvement and postimprovement of compressible soft clay. Pressures required to inflate the attached membrane were measured, and the pressure during the deflation was measured. These measured pressures were used to classify the soils and interpret the geotechnical parameters. The details of DMTs carried out in these projects are described by Arulrajah et al. (2004a) and Chang et al. (1998).

Table 3. Numbers of boreholes, SPT and FVT carried out in Changi East Reclamation projects

\begin{tabular}{|c|c|c|c|c|c|c|}
\hline & & & Pro & & & \\
\hline & Phase $1 \mathrm{~A}$ & Phase 1B & Phase $1 \mathrm{C}$ & Area A (north) & Area A (south) & Total \\
\hline Number of offshore boreholes & 82 & 75 & 139 & 10 & 51 & 357 \\
\hline Number of offshore SPTs & 941 & 441 & 1461 & 176 & 820 & 3839 \\
\hline Number of offshore FVTs & 40 & 99 & 118 & 10 & 43 & 310 \\
\hline Number of land boreholes & 112 & 162 & 211 & 64 & 51 & 600 \\
\hline Number of land SPTs & 1216 & 848 & 1524 & 669 & 246 & 4503 \\
\hline Number of land FVTs & 35 & 193 & 188 & 62 & 76 & 554 \\
\hline Total number of boreholes & 194 & 237 & 350 & 74 & 102 & 957 \\
\hline Total number of SPTs & 2157 & 1289 & 2985 & 845 & 1066 & 8342 \\
\hline Total number of FVTs & 75 & 292 & 306 & 72 & 119 & 864 \\
\hline
\end{tabular}


Table 4. Types of in situ specialised test, measured parameters and interpreted geotechnical parameters

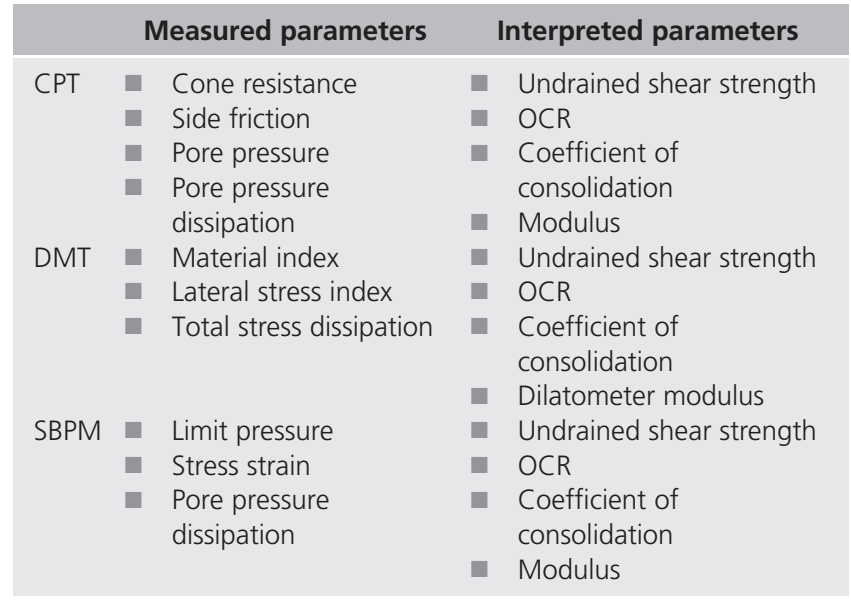

\section{SELF-BORING PRESSUREMETER}

SBPMTs were carried out to obtain the stress-strain characteristics of soils and the limit pressures of the soils and interpreted geotechnical parameters. SBPMTs were also carried out pre- and post-ground improvement to verify the improvement of the soils.

Dissipation tests were carried out using CPTU, DMT and SBPMT. From the dissipation tests, the coefficient of consolidation due to horizontal flow $\left(C_{\mathrm{h}}\right)$ was interpreted to be used in the design of ground improvement works.

Details of SBPMT and dissipation tests using various specialised in situ equipment are described in detail in the studies Bo and Choa (2004), Bo et al. (2000, 2003), Arulrajah et al. (2005, 2006a, 2006b, 2007, 2009, 2011) and $\mathrm{Na}$ et al. (1999).

\section{BENGT-ARNE TORSTENSSON PERMEAMETER TESTS}

Hydraulic conductivity tests were carried out using a Bat permeameter applying both inflow and outflow methods. Hydraulic conductivity parameters were also interpreted from in situ dissipation tests using CPTU, DMT and SBPM. Details of those studies can be found in the studies by Bo et al. (1998a, 2014).

\section{SEISMIC CONE TESTS}

Several SCTs were carried out prior to the improvement and postimprovement of granular soils. A seismic cone was pushed into the granular soils, which registered cone resistances and side frictions. At the depth of interest, seismic waves were generated and measured. Shear wave velocities and shear modulus were interpreted from the measurements. Details of SCTs carried out in these projects are described in the study by Bo and Choa (2004).

\section{CONE PRESSUREMETER TESTS}

CPMTs were carried out to measure cone resistance, side friction, pore pressure during penetration as well as stress-strain characteristics of soil and limit pressure at selected depths. CPTs were carried out the same way as CPTUs, and pressuremeter tests were carried out the same way as SBPTs. The advantage of using CPMT is that it does not require pre-boring to carry out the pressuremeter test. It is very useful in carrying out within the granular fill, in which stable dimensions of boreholes are difficult to maintain. Measured and interpreted parameters obtained are a combination of those parameters obtained from CPTU and SBPMT. Details of CPMTs carried out in these projects are described in the studies by Bo and Choa (2004) and Cao et al. (1998).

\section{GAMMA-GAMMA PROBE}

The gamma-gamma probe was extensively used to measure the in situ bulk unit weight of slurry in a silt pond at the various depths. As the silt pond is filled with fine tailings in a stage of fluid, the gamma-gamma probe can be sunk into the fluid without the necessity of drilling a hole. The gamma-gamma probe measures the unit weight of the material.

\section{PLATE LOAD TESTS}

Many PLTs were also carried out on granular soils prior to and after improvement to determine the modulus of elasticity of the improved soils. From the load-settlement curves, the moduli of subgrade were interpreted for the reclamation fills.

\section{SCREW PLATE TESTS}

In addition to the PLTs carried out on the surface as well as in the shallow excavated pits, screw plates were penetrated and installed at

Table 5. Numbers of CPTs carried out at Changi East Reclamation projects

\begin{tabular}{|c|c|c|c|c|c|c|}
\hline & \multicolumn{5}{|c|}{ Projects } & \multirow{2}{*}{ Total } \\
\hline & Phase $1 \mathrm{~A}$ & Phase 1B & Phase $1 \mathrm{C}$ & Area A (north) & Area A (south) & \\
\hline Number of offshore CPTs & 0 & 162 & 168 & 4 & 37 & 371 \\
\hline Number of land CPTs (PVD-CPT included) & 990 & 2666 & 3674 & 881 & 1707 & 9918 \\
\hline Number of CPT dissipation holding tests & 0 & 42 & 0 & 0 & 6 & 48 \\
\hline Number of CPT long-term holding tests & 56 & 74 & 119 & 64 & 26 & 339 \\
\hline Number of precompaction CPTs & 524 & 500 & 750 & 0 & 9 & 1783 \\
\hline Number of post-compaction CPTs & 910 & 1218 & 1765 & 0 & 374 & 4267 \\
\hline Total number of CPTs & 990 & 2828 & 3842 & 885 & 1744 & 10289 \\
\hline Total number of CPT holding tests & 56 & 116 & 119 & 64 & 32 & 387 \\
\hline Total number of compaction CPTs & 1434 & 118 & 2515 & 0 & 383 & 6050 \\
\hline Grand total number of CPTs excluding holding CPT & 2424 & 4546 & 6357 & 885 & 2127 & 16339 \\
\hline
\end{tabular}


Research-oriented ground investigation

projects at Changi, Singapore

Bo, Arulrajah, Choa, Horpibulsuk and Samingthong the depths of interest and PLTs carried out at various depths to determine the modulus of elasticity and stress-strain characteristics of granular soils both prior to improvement and post-improvement.

\section{RAM SOUNDING TESTS}

Heavy-duty RSTs were carried out prior to the improvement and post-improvement of granular soils. Correlations were also developed for obtaining standard penetration test (SPT) values from RSTs. Details can be found in the studies by Bo and Choa (2004) and $\mathrm{Na}$ et al. (1999).

The parameters obtained from prior to land reclamation investigations were used for the design of land reclamation, ground improvement, shore protection and retaining structures, whereas those obtained from site investigation during ground improvement were used for the monitoring of the progress of ground improvement. Those geotechnical parameters obtained from post-ground improvement site investigation were used for verifying the achievement of ground improvement. Figure 3 shows the comparison of geotechnical parameters obtained from pre- and post-ground improvement. Table 6 gives the number of specialised in situ tests carried out in Changi East Reclamation projects.

\section{Laboratory testing}

For each of the five phases of project implementation, one laboratory was set up to carry out both conventional geotechnical laboratory testing and specialised laboratory testing to develop geotechnical parameters required for the design of land reclamation, shore protections and ground improvement works as well as monitoring of the improvement of improved soil parameters during and after the completion of ground improvement.

Each laboratory was equipped to carry out classification tests such as moisture content, Atterberg's limits, shrinkage limit, grain size distribution, hydrometer tests, specific gravity and organic content tests. Standard strength tests such as direct shear; various kinds of triaxial tests, such as unconsolidated and consolidated undrained and drained tests; and conventional

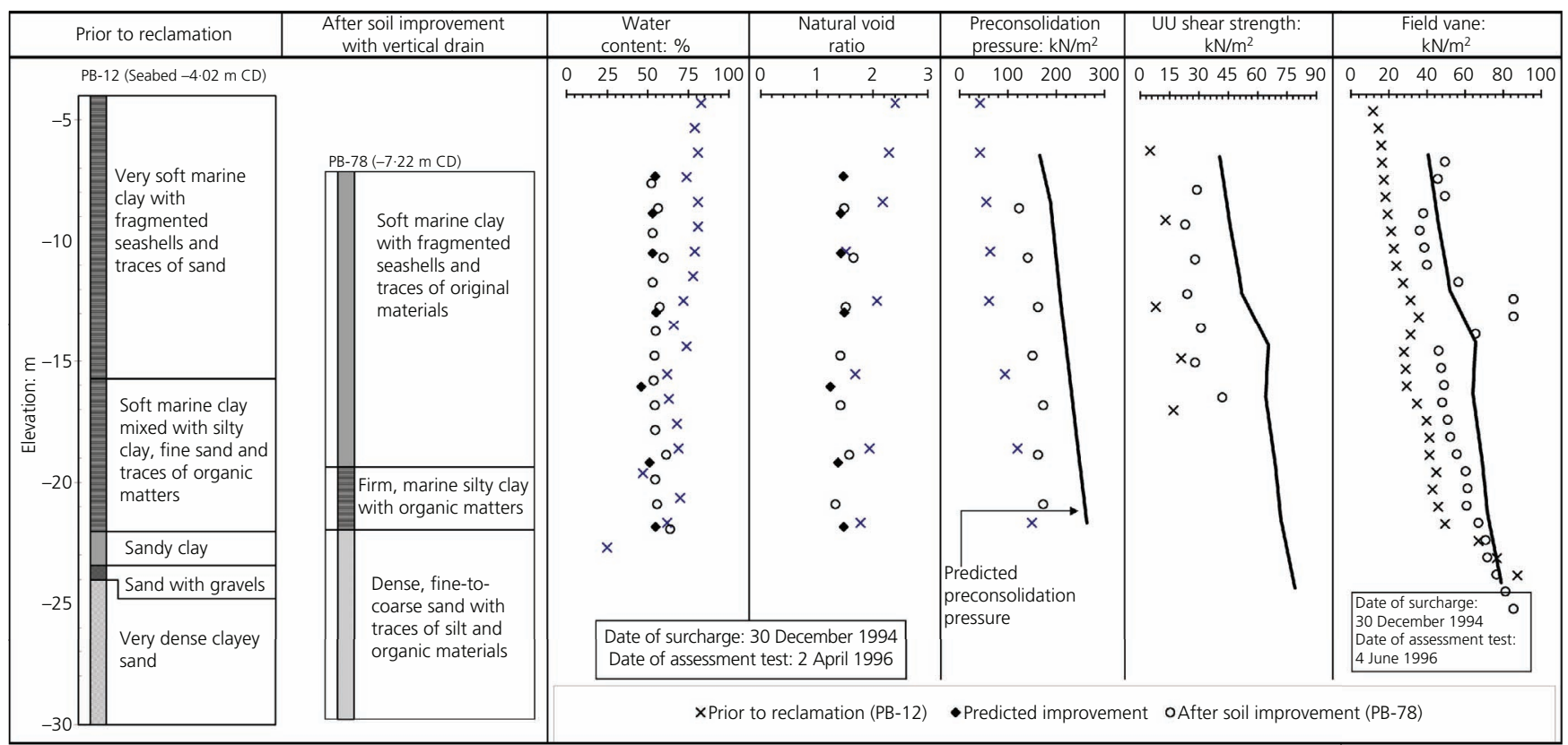

Figure 3. Comparison of geotechnical parameters obtained from pre- and post-ground improvement (Bo and Choa, 2004)

Table 6. Numbers of specialist in situ tests carried out at Changi East Reclamation projects

\begin{tabular}{lccccrr} 
& \multicolumn{4}{c}{ Projects } \\
\cline { 2 - 5 } & Phase 1A & Phase 1B & Phase 1C & Area A (north) & Area A (south) \\
DMT & 0 & 11 & 10 & 2 & 4 & 27 \\
SBPT & 0 & 11 & 10 & 2 & 4 & 27 \\
Bat & 0 & 8 & 27 & 2 & 6 & 0 \\
CPMT & 0 & 85 & 31 & 0 & 243 \\
Ram sounding & 78 & 1463 & 0 & 0 & 0 \\
Seismic cone & 0 & 3 & 0 & 0 & 3 \\
In situ permeability test & 0 & 0 & 10 & 0 & 116 \\
\end{tabular}


Table 7. Numbers of various conventional and specialised laboratory tests carried out at the Changi East Reclamation projects

\begin{tabular}{|c|c|c|c|c|c|c|}
\hline & Phase 1A & Phase 1B & Phase 1C & Area (north) & Area A (south) & Total \\
\hline Moisture content & 1640 & 2250 & 4170 & 400 & 1530 & 9990 \\
\hline Atterberg limits & 820 & 1130 & 2085 & 200 & 765 & 5000 \\
\hline Laboratory vane tests & 820 & 1130 & 2085 & 200 & 765 & 5000 \\
\hline Grain size distribution & 3250 & 3750 & 3400 & 600 & 2600 & 13600 \\
\hline Hydrometer & 820 & 1130 & 2085 & 200 & 765 & 5000 \\
\hline Specific gravity & 205 & 283 & 520 & 50 & 190 & 1248 \\
\hline Organic content & 100 & 100 & 200 & 25 & 50 & 475 \\
\hline UU & 410 & 565 & 1040 & 100 & 380 & 2495 \\
\hline Direct shear & 205 & 280 & 520 & 50 & 190 & 1245 \\
\hline CIU triaxial & 5 & 30 & 50 & 5 & 20 & 110 \\
\hline CID triaxial & 5 & 30 & 40 & 5 & 15 & 95 \\
\hline$C K_{0} \mathrm{U}$ triaxial & - & 10 & 20 & 5 & 10 & 45 \\
\hline Shansep & - & 5 & 5 & 2 & 3 & 15 \\
\hline Oedometer & 410 & 565 & 1040 & 100 & 380 & 2495 \\
\hline Rowe cell & - & 50 & 100 & 10 & 20 & 180 \\
\hline CRS & - & 10 & 30 & 5 & 10 & 55 \\
\hline CRL & - & 10 & 30 & 5 & 10 & 55 \\
\hline XRD & 5 & 5 & 5 & 5 & 5 & 25 \\
\hline SEM & 5 & 5 & 5 & 5 & 5 & 25 \\
\hline
\end{tabular}

UU, unconsolidated undrained; CIU, isotropically consolidated undrained; CID, isotropically consolidated drained; CKo history and normalised soil engineering properties; XRD, X-ray diffraction; SEM, scanning electron microscopy

oedometer consolidation tests could be carried out in these laboratories.

In addition to the conventional laboratory set-up, each laboratory also included specialised equipment such as the Bishop and Horsley stress path equipment to be able to perform stress path tests and a hydraulic Rowe cell to carry out consolidation tests under various drainage conditions to obtain the coefficient of consolidation due to horizontal flow. The hydraulic Rowe cell was also extensively used to carry out end-of-primary (EOP) consolidation tests, constant rate of loading (CRL) and constant rate of strain (CRS) tests to obtain compression and consolidation parameters under various rates of loading and strain rates.

Table 7 gives the numbers of various conventional and specialised laboratory tests carried out in various phases of the projects.

\section{Photographic identification}

Photographic identification of the marine clay obtained from the marine sampling boreholes was carried out with a high-resolution camera. The marine clay specimens were extruded, and the entire length of the specimen was carefully cut and subsequently opened in two different ways: by cutting it with a wire saw and by splitting it open without cutting it. Opening the specimen exposed the inner core of the specimen to enable identification of the textures and laminations of the marine clay. Figure 4 shows the photographic identification of the upper marine clay. The colour of the marine clay was compared with colour charts to describe the colour of the various layers of marine clay. Photographic identification enables the characterisation of the colours, textures and laminations of the marine clay. The identification depths of the sand seams, organic material and layers of past exposure to oxidation are also evident.

\section{Mineralogy tests on marine clay}

The mineralogy of the marine clay was determined by the extraction of piston samples for X-ray diffraction (XRD) and scanning electron microscopy (SEM) analyses.

\section{X-ray diffraction}

The XRD analysis was conducted using a Philips PW1700 series diffractometer equipped with a cobalt target tube and operated at $45 \mathrm{kV}$ and $40 \mathrm{~mA}$. The clay mineralogy of the air-dried and glycolsolvated samples was determined using oriented mounts from 1.5 to $32^{\circ} 2 \theta$ with $0.48^{\circ} 2 \theta / \mathrm{min}$, where $\theta$ was the diffraction angle. The diffraction data were analysed using Philips APD1700 software coupled with a Joint Committee on Powder Diffraction Standards

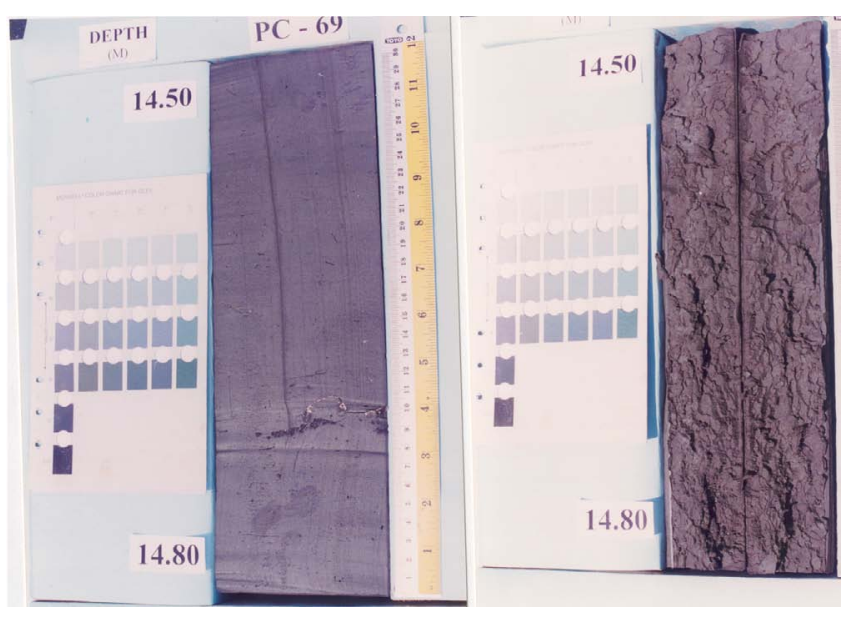

Figure 4. Photographic identification of upper marine clay (Bo et al., 2015a) 
Research-oriented ground investigation

projects at Changi, Singapore

Bo, Arulrajah, Choa, Horpibulsuk and Samingthong database running on a Dec MicroVax 2000 microcomputer system. Figure 5 shows the XRD patterns for various depths.

\section{Scanning electron microscopy}

The SEM specimens were examined in an energy-dispersive X-ray analysis system, which provided qualitative chemical information from areas of interest. An accelerating voltage of $20 \mathrm{kV}$ was used throughout this study. The concentration qualitative chemistry of each clay mineral is identified on the list of elements detected.

Figure 6 shows the SEM micrographs for the marine clay (plates 1-3, upper marine clay; plates 4-6, lower marine clay) showing the content of kaolinite and smectite minerals and their pore sizes.

Details of the photographic identification and XRD and electron microscope analyses can be found in the studies by Bo et al. (2015a, 2015b).

\section{Consolidation tests}

The following consolidation tests were carried out in order to characterise the stress strain-dependent compressibility behaviour of Singapore marine clay

- one-dimensional (1D) oedometer tests with various load increment ratios

- 1D oedometer tests with various loading duration on each step between 12 and $72 \mathrm{~h}$

EOP tests

- isotropic consolidation tests

- CRL tests

- CRS tests

- consolidation tests using a hydraulic Rowe cell with various combinations of drainage

- consolidation tests in a large-diameter tank with pore pressure measurements in various locations within the samples.

\section{Oedometer tests}

Oedometer consolidation tests were carried out using $19 \mathrm{~mm}$ high and $63.5 \mathrm{~mm}$ dia. oedometer rings. A standard oedometer ring was pressed into the $100 \mathrm{~mm}$ sample, and the sample together with the ring was detached from the extruded sample using a wire saw. Loads were applied in stages from 25 to $1600 \mathrm{kPa}$ with a load incremental ratio of unity. Each step of load was applied either for $24 \mathrm{~h}$ or until the EOP. However, tests with longer duration were also conducted to study the secondary compression behaviour of the soil.

\section{Constant rate of strain tests}

The CRS tests were carried out using a modified triaxial cell on specimens that were trimmed inside the standard oedometer ring. The dimensions of the samples were identical to the oedometer samples. Drainage was from the top, and the pore water pressure was measured at the centre of the bottom boundary. The strain rates used for different tests varied between 1.3 and $10 \cdot 47 \% / \mathrm{h}$ $(0 \cdot 25-2 \cdot 00 \mathrm{~mm} / \mathrm{h})$. Details on the constant rate of displacement tests can be found in the studies by Bo et al. $(2008,2009)$.

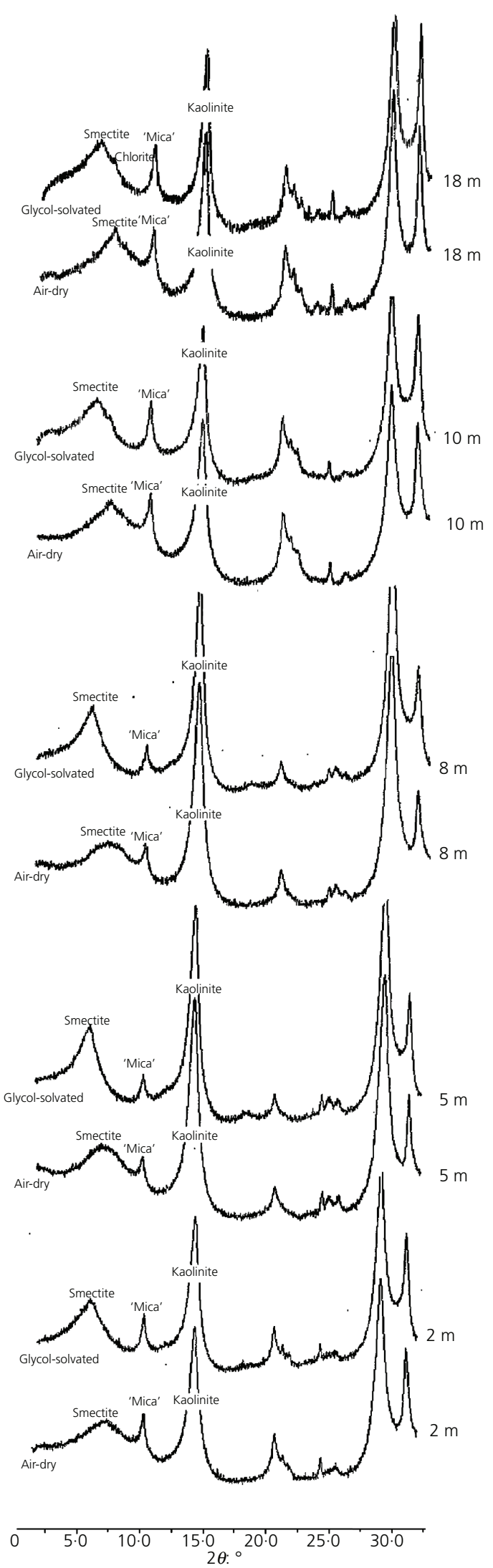

Figure 5. XRD patterns of marine clay samples (Bo et al., 2015a) 
Geotechnical Research

Volume 4 Issue GR1
Research-oriented ground investigation

projects at Changi, Singapore

Bo, Arulrajah, Choa, Horpibulsuk and Samingthong

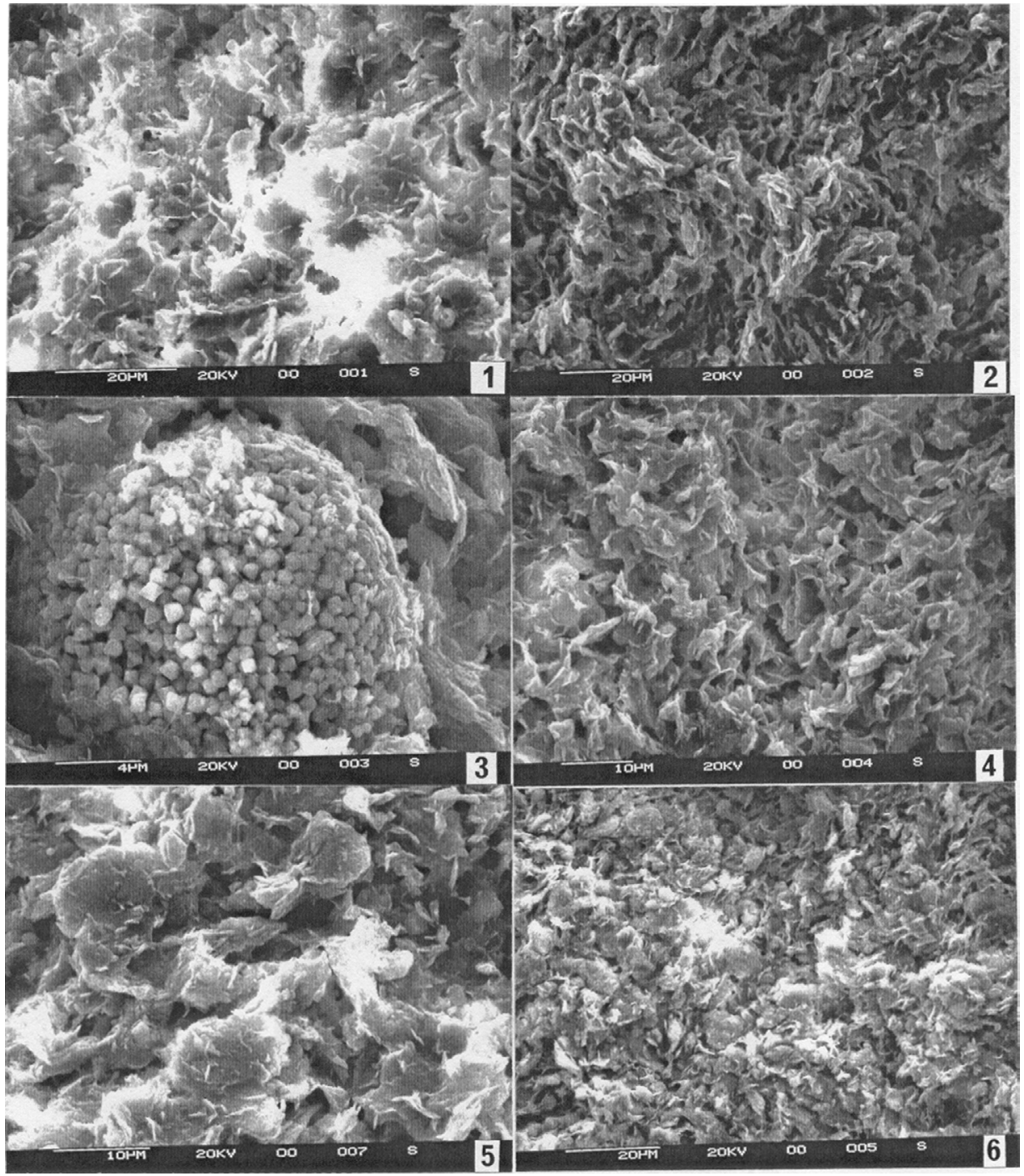

Figure 6. SEM micrographs of marine clay: plates 1-3 for upper marine clay and plates 4-6 for lower marine clay (Bo et al., 2015a)

\section{Constant rate of loading tests}

The CRL tests were carried out using a modified triaxial cell on specimens that were trimmed inside the standard oedometer ring. The dimensions of the samples were identical to the oedometer samples. Drainage was from the top, and the pore water pressure was measured at the centre of the bottom boundary. The loading rates used for different tests varied between 3 and $9 \mathrm{kPa} / \mathrm{h}$. Details of the CRL tests carried out at Changi Reclamation projects can be found in the study by Bo et al. (2010).

\section{Rowe cell tests}

The Rowe cell tests were carried out primarily to measure the coefficient of consolidation in the horizontal direction (Chu et al., 2002), but were also used to estimate the compressibility properties of the soil, although the horizontal drainage could slightly affect the compressibility of the soil (Atkinson et al., 1985; Houlsby and Nageswaran, 1982). Rowe cells of diameters of 150 and $75 \mathrm{~mm}$ were used. Pore water pressure was measured at the centre of the bottom boundary. The following types of consolidation tests were carried out

vertical drainage under either EOP or CRS load

- horizontal drainage to the centre under EOP load

- horizontal drainage to the side boundary under EOP or CRS load.

EOP determinations on these tests were based on the pore pressure measurement at the base of the sample.

\section{Isotropic consolidation test}

For the completeness of the study, isotropic consolidation tests were also carried out using a triaxial cell on $38 \mathrm{~mm}$ dia. and $76 \mathrm{~mm}$ high specimens to establish the isotropic compression line. Details of these tests can be found in the study by Bo et al. 
Research-oriented ground investigation

projects at Changi, Singapore

Bo, Arulrajah, Choa, Horpibulsuk and Samingthong
(2016). Details of consolidation tests on Singapore marine clay can be found in the study by Chu et al. (2004). One-dimensional consolidation tests on Singapore marine clay were extensively discussed by Bo et al. (1998c, 2001b, 2016).

\section{Strength tests}

The following strength tests were carried out in order to study the stress strain-dependent strength characteristics of Singapore marine clay

- unconsolidated undrained (UU) tests

- isotropically consolidated undrained (CIU) tests

- isotropically consolidated drained (CID) tests

- $K_{0}$ consolidated undrained $\left(\mathrm{C} K_{0} \mathrm{U}\right)$ tests

- $K_{0}$ consolidated drained $\left(\mathrm{C} K_{0} \mathrm{D}\right)$ tests

- direct shear tests

- stress history and normalised soil engineering properties (Shansep) tests

- stress path tests

- strain path tests

- laboratory vane tests.

Details of these tests can be found in the study by Bo and Choa (2004).

Table 7 gives the numbers of various conventional and specialised laboratory tests carried out in Changi East Reclamation projects. Table 8 gives the comparison of compression parameters from various consolidation tests. The strength and consolidation behaviour of Singapore marine clay was discussed by Chang et al. (2001), Choa et al. (1996) and Chu et al. (1999).

\section{Correlation of compressibility parameters with physical parameters}

It was tried to correlate compressibility parameters obtained from an oedometer test, especially compression index $\left(C_{\mathrm{c}}\right)$, with physical parameters such as natural moisture content, void ratio, liquid limit and plastic index.

For Singapore marine clay, there are two different correlations between compression index and physical parameters. One is for upper marine clay and the other is for lower marine clay. The following correlations are found between compression index and moisture content, liquid limit and void ratio. These correlations were obtained by applying regression analyses using large amounts of laboratory data collected during the implementation of three earlier phases, and validations were made in the last two phases. Most correlations proposed here yield $R^{2}$ values of generally greater than $95 \%$. Due to the thin nature of intermediate clay and its low compressibility, the correlation of such layers was not carried out

upper marine clay

1a. $C_{\mathrm{c}}=0 \cdot 025(W-32 \cdot 5)$

1b. $C_{\mathrm{c}}=0.02\left(L_{\mathrm{L}}-56\right)$

1c. $C_{\mathrm{c}}=1 \cdot 18\left(e_{0}-1\right)$

- lower marine clay

2a. $C_{\mathrm{c}}=0 \cdot 0125(W-11)$

2b. $C_{\mathrm{c}}=0 \cdot 008\left(L_{\mathrm{L}}-14\right)$

2c. $C_{\mathrm{c}}=0 \cdot 512\left(e_{0}-0 \cdot 28\right)$

It was found that the correlation for Singapore lower marine clay is similar to the Terzaghi and Peck (1967) correlation.

\section{Correlation of strength parameters with physical and consolidation parameters}

\section{Correlation between field vane strength and natural} moisture content

It would be meaningful when strength parameters could be obtained from physical parameters such as natural moisture content or Atterberg's limits. Figure 7 shows the relationship between undrained shear strength obtained from field vane test and natural moisture content. These two parameters hold the relationship with the following equation for both upper and lower marine clays. This correlation is obtained from regression analyses using field vane shear tests data and moisture content test data collected from the same formation at the same level of depths

3. $s_{\mathrm{u}}(\mathrm{FVT})=253 \cdot 77-3 \cdot 307 W$

Table 8. Comparison of compression and recompression indices from various consolidation tests

\begin{tabular}{|c|c|c|c|c|c|c|c|c|c|}
\hline & $24 \mathrm{~h}$ & EOP & $\mathrm{RC}(1)$ & $\mathrm{RC}(3)$ & $\mathrm{RC}(4)$ & CRS $0.5 \mathrm{~mm} / \mathrm{h}$ & CRS: $1.0 \mathrm{~mm} / \mathrm{h}$ & CRS: $1.5 \mathrm{~mm} / \mathrm{h}$ & CRS $2.0 \mathrm{~mm} / \mathrm{h}$ \\
\hline$C_{c}$ & 0.86 & 0.76 & 0.98 & 0.89 & 0.89 & 0.91 & $1 \cdot 15$ & 0.94 & $1 \cdot 23$ \\
\hline$C_{r}$ & 0.07 & 0.06 & 0.12 & - & - & - & - & - & - \\
\hline
\end{tabular}




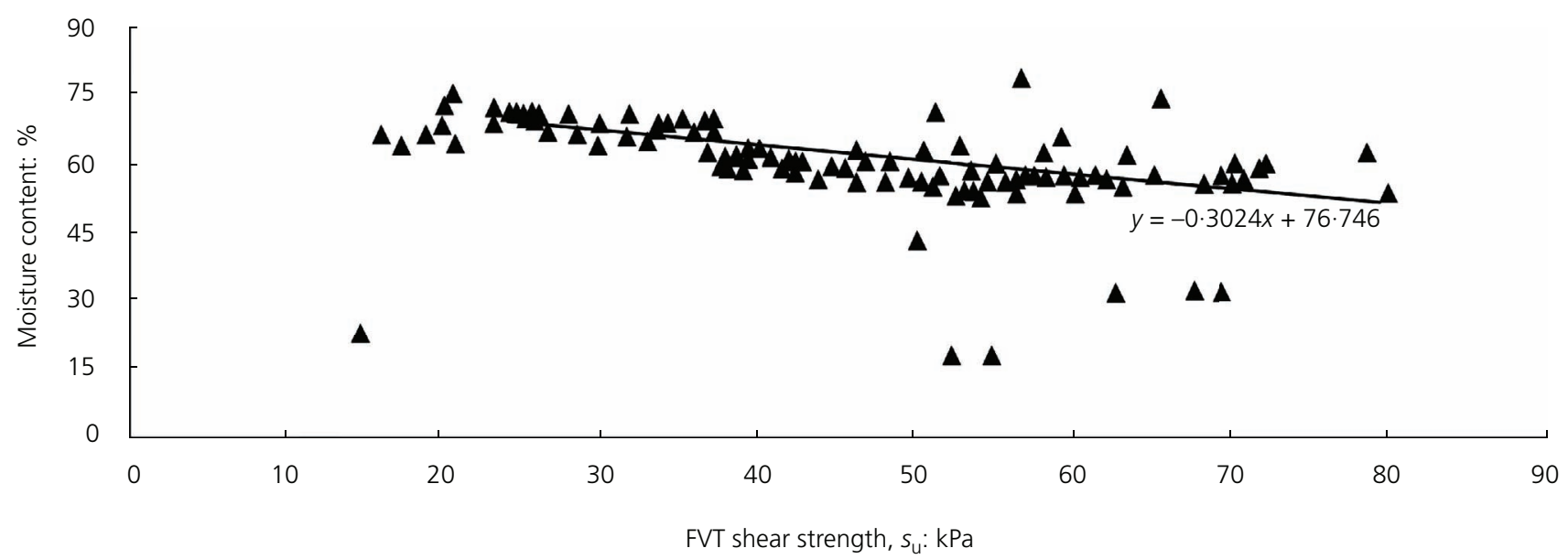

Figure 7. Correlation between undrained shear tests obtained from FVTs and natural moisture content

\section{Correlation of normalised undrained shear strength with \\ OCR}

Several Shansep tests were carried out in order to find out the similar relationship for Singapore upper and lower marine clays, and Figures 8(a) and 8(b) show the relationship that can be expressed by following equations

upper marine clay

4. $s_{\mathrm{u}} / \sigma_{\mathrm{v}}^{\prime}=0 \cdot 18(\mathrm{OCR})^{0.75}$ n lower marine clay

5. $s_{\mathrm{u}} / \sigma_{\mathrm{v}}^{\prime}=0 \cdot 23(\mathrm{OCR})^{0.75}$

The resulting correlation is similar to the relationship proposed by Ladd et al. (1977). The correlations above were obtained from regression analyses using laboratory-consolidated undrained shear tests applying the Shansep method. Likewise, $s_{\mathrm{u}} / \sigma_{\mathrm{v}}^{\prime}$ from field vane shear strength was worked out using field vane test results and laboratory consolidation test results on the samples at the

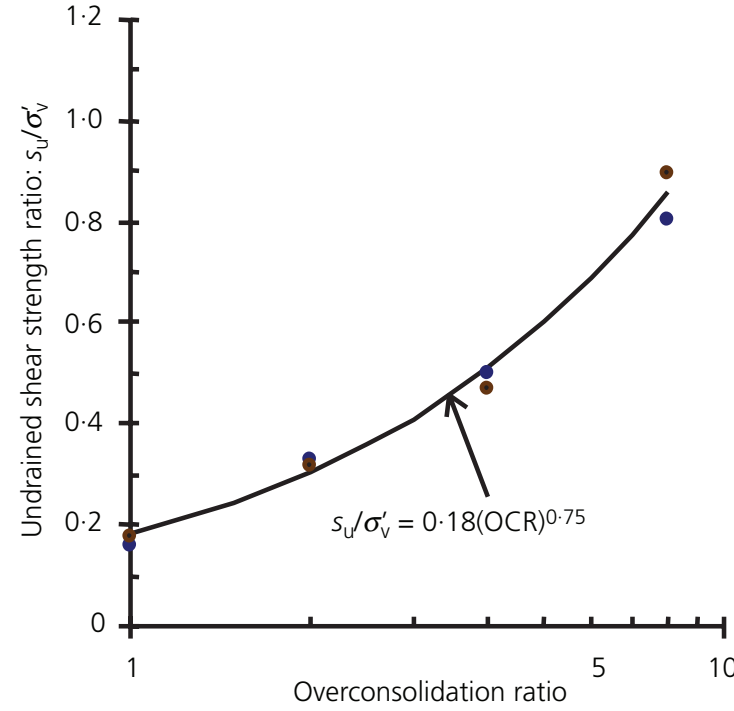

(a)

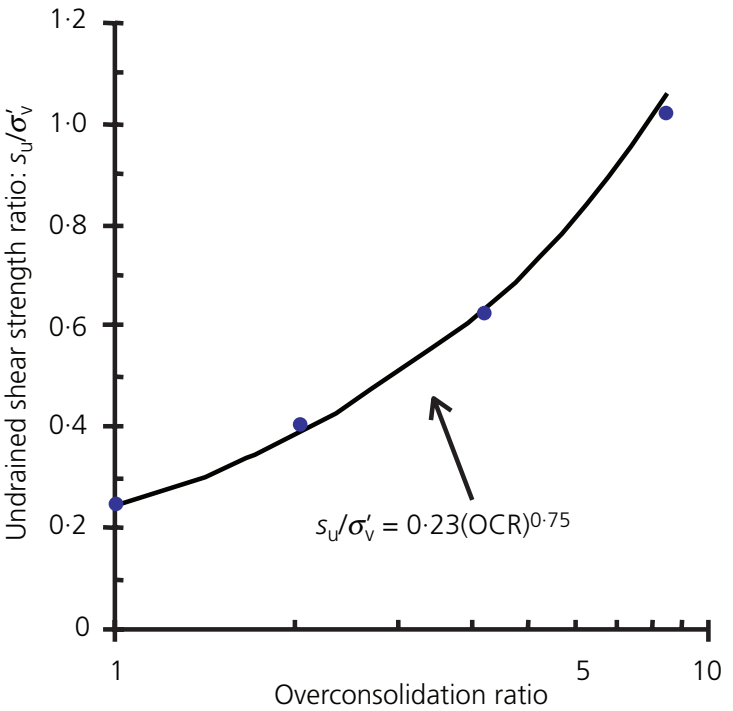

(b)

Figure 8. Correlation between normalised undrained shear strength and overconsolidation ratio of (a) upper marine clay and (b) lower marine clay 
Research-oriented ground investigation

projects at Changi, Singapore

Bo, Arulrajah, Choa, Horpibulsuk and Samingthong

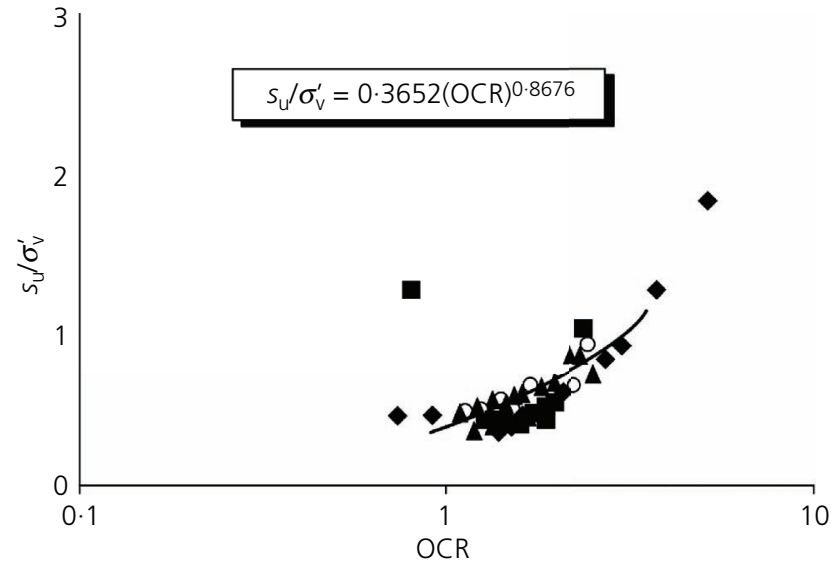

Figure 9. Correlation between normalised field vane shear strength and OCR

same depths, and Figure 9 shows that the relationship holds the following equation

6. $\frac{s_{\mathrm{u}}}{\sigma_{\mathrm{v}}^{\prime}}=0 \cdot 3652(\mathrm{OCR})^{0.87}$

The relationship is also quite similar to that proposed by Ladd et al. (1977).

\section{Correlation of strength parameters with in situ measured parameters}

\section{Correlation of cone resistance with undrained shear} strength

The evaluation of the undrained shear strength $\left(s_{\mathrm{u}}\right)$ of clay from the corrected cone resistance $\left(q_{\mathrm{t}}\right)$ as obtained in the CPTU is usually based on the bearing capacity theory

7. $s_{\mathrm{u}}=\left(q_{\mathrm{t}}-\sigma_{\mathrm{vo}}\right) / N_{\mathrm{kt}}$

where $\sigma_{\mathrm{vo}}$ is total overburden pressure and $N_{\mathrm{kt}}$ is the cone factor.

The relationship between $q_{\mathrm{t}}$ and $s_{\mathrm{u}}$ is not universal, and it depends on the type of clay and the field or laboratory test on which the $s_{\mathrm{u}}$ value is based. Published data show that there is a large scatter of the inferred $N_{\mathrm{kt}}$ values for different clays. For example, De Ruiter (1982) reported that the typical values of $N_{\mathrm{kt}}$ were $10-15$ for normally consolidated clay and 15-21 for the on-land Singapore marine clay, which is generally lightly overconsolidated. However, the range of the $N_{\mathrm{kt}}$ values reported by both has a maximum difference of 5-6. This variation in $N_{\mathrm{kt}}$ values could lead to a $30-40 \%$ difference in the predicted undrained shear strength.

Aas et al. (1986) proposed a relationship between $N_{\mathrm{kt}}$ and the plastic index $\left(P_{\mathrm{I}}\right)$ of clay as follows
8. $\quad N_{\mathrm{kt}}=13+(5 \cdot 5 / 50) P_{\mathrm{I}}( \pm 2)$

Cao (1997), based on cavity expansion theory and a modified Cam clay concept, described that the correlation between the undrained shear strength, $s_{\mathrm{u}}$, and the cone penetration resistance, $q_{\mathrm{t}}$, is influenced by the stress history of soil and critical state soil parameters. Bo et al. (1998b) proposed an empirical correlation between $N_{\mathrm{kt}}$ and the plastic index based on field vane test data and CPTU data from the Singapore marine clay (Figure 10), and the correlation is as follows

9. $N_{\mathrm{kt}}=23 \cdot 8-\left(0 \cdot 263 P_{\mathrm{I}}\right)$

Equation 9 shows that $N_{\mathrm{kt}}$ decreases with $P_{\mathrm{I}}$, although a correlation proposed by Aas et al. (1986) indicates that $N_{\mathrm{kt}}$ increases with the plastic index. Earlier, Lunne et al. (1976) also showed a similar trend of decreasing cone factor with plastic index. Details of undrained shear strength interpretation from in situ tests could be found in the study by Bo et al. (2000). The correlations above are obtained by applying regression analyses from a large database using the $N_{\mathrm{kt}}$ calculated from the measured cone and field vane shear strengths from the same location and depth and the plastic index measured from the sample collected from the same location and depths.

\section{Correlation of lateral stress index with undrained shear strength}

Like CPT, $s_{\mathrm{u}}$ can also be estimated from $K_{\mathrm{D}}$ values obtained from DMT. Marchetti (1980) proposed the undrained shear strength $s_{\mathrm{u}}$ with lateral stress index $K_{\mathrm{D}}$ as follows

10. $s_{\mathrm{u}}=0 \cdot 22 \sigma_{\mathrm{vo}}^{\prime}\left(\frac{K_{\mathrm{D}}}{2}\right)^{1 \cdot 25}$

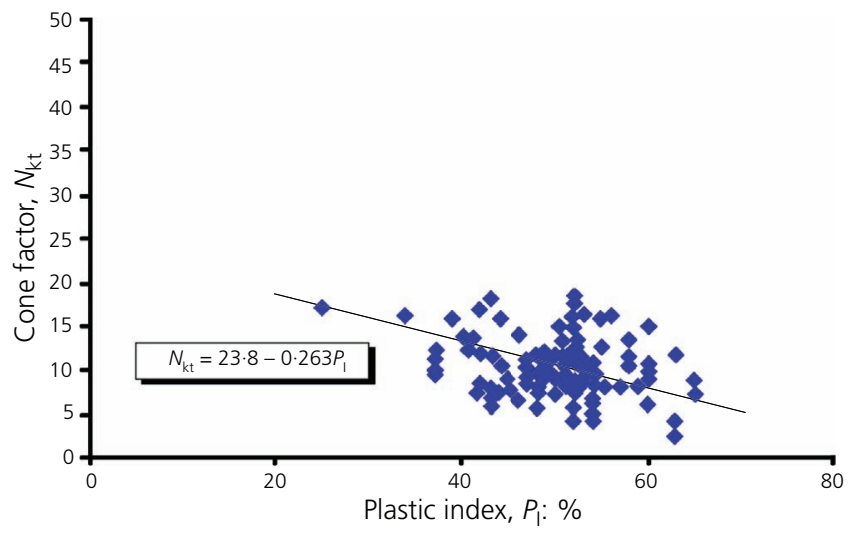

Figure 10. Correlation between cone factor $\left(N_{\mathrm{kt}}\right)$ and plastic index $\left(P_{1}\right)$ 
where $\sigma_{\mathrm{vo}}^{\prime}$ is effective vertical stress and $K_{\mathrm{D}}$ is the lateral stress index. Bo et al. (2000) proposed the power function as 1.0 for upper and intermediate Singapore marine clay and 0.7 for lower Singapore marine clay, instead of $1 \cdot 25$. Figure 11 shows the $s_{\mathrm{u}}$ values estimated from DMT.

\section{Correlation of limit pressure with undrained shear strength}

Undrained shear strength can also be estimated from limit pressure using the following equation

$$
\text { 11. } s_{\mathrm{u}}=\frac{P_{\mathrm{L}}-\sigma_{\mathrm{ho}}}{N_{\mathrm{p}}}
$$

where

$$
\text { 12. } N_{\mathrm{p}}=1+\log _{\mathrm{e}}\left(\frac{G}{S_{\mathrm{u}}}\right)
$$

where $P_{\mathrm{L}}$ is the limit pressure, $\sigma_{\mathrm{ho}}$ is the in situ total horizontal stress, $G$ is shear modulus, $s_{\mathrm{u}}$ is undrained shear strength and $N_{\mathrm{p}}$ is a pressuremeter constant. Marsland and Randolph (1977) adopted as $N_{\mathrm{p}}$ ranging between $5 \cdot 5$ and $6 \cdot 8$. It could again be suggested that the $N_{\mathrm{p}}$ values for specific clay should be locally obtained by empirical correlation. Bo et al. (2000) suggested that $N_{\mathrm{p}}$ values for Singapore marine clay at Changi are $6 \cdot 0,6 \cdot 4$ and $7 \cdot 2$ for upper, intermediate and lower marine clay, respectively. Figures 11 and 12 also show comparisons between field vane shear strength and that interpreted from SBPT. This correlation was obtained by applying regression analyses using many sets of pressuremeter tests and field vane shear strength tests carried out site by site at many locations and depths at Changi, Singapore.

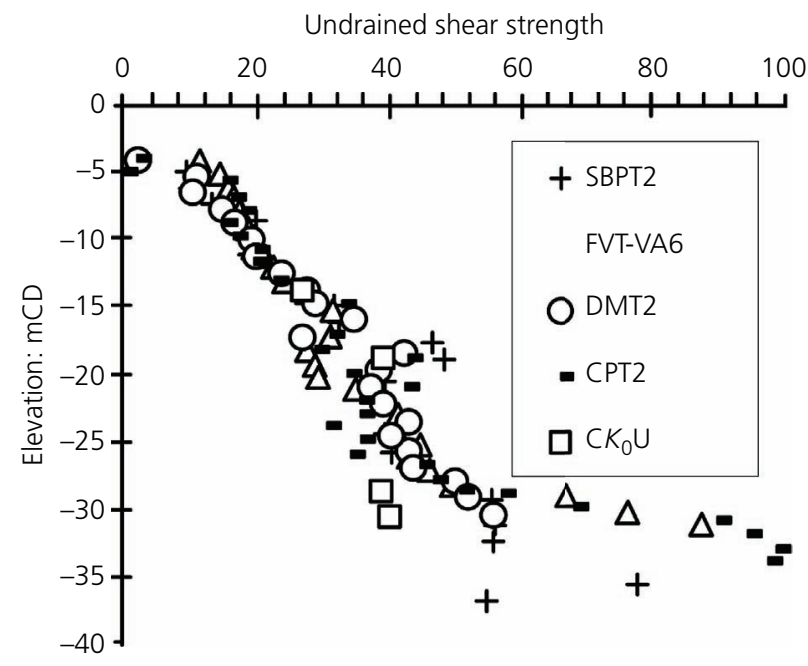

Figure 11. Undrained shear strength interpreted from specialised in situ tests (Bo and Choa, 2004)

\section{Correlation of OCR with in situ measured parameters}

Correlation of cone resistance with OCR

Profiling of OCR in clays by piezocone soundings was widely discussed by Mayne and Bachus (1988). Sugawara (1988) proposed the following equation for estimating OCR from clay

13. $\left(q_{\mathrm{t}}-\sigma_{\mathrm{vo}}\right) / \sigma_{\mathrm{vo}}^{\prime}=k \mathrm{OCR}$

where $k$ is the coefficient of constant

The interpretation of the OCR of Singapore marine clay from cone penetration tests was also described by Chang (1991). Chang et al. (1997) proposed the correlation of OCR with pore pressure parameters $B_{\mathrm{q}}$ as follows

14. $\mathrm{OCR}=2 \cdot 3 B_{\mathrm{q}} /\left(3 \cdot 7 B_{\mathrm{q}}-1\right)$

Cao et al. (1996) proposed the correlation between OCR, cone resistance $\left(q_{\mathrm{t}}\right)$ and pore pressure $\left(u_{\mathrm{bt}}\right)$ using critical state soil parameters as follows

$$
\mathrm{OCR}=2\left(\frac{0 \cdot 866 q_{\mathrm{t}}+0 \cdot 134 \sigma_{\mathrm{vo}}-u_{\mathrm{bt}}}{\alpha_{\varepsilon} \sigma_{\mathrm{vo}}^{\prime}(1+0 \cdot 66 M)}\right)^{1 / \Lambda}
$$

15. for $B_{\mathrm{q}}=<0.75$

$$
\mathrm{OCR}=2\left(\frac{q_{\mathrm{t}}-u_{\mathrm{bt}}}{\alpha_{\varepsilon} \sigma_{\mathrm{vo}}^{\prime}(1+0 \cdot 67 M)}\right)^{1 / \Lambda}
$$

16. for $B_{\mathrm{q}}=0.75-0.85$

where $\Lambda$ is the coefficient of constant with value of 0.75 and $M=$ $6 \sin \phi^{\prime} /\left(3-\sin \phi^{\prime}\right)$.

The estimation of OCR from the CPT can be based on the net corrected cone resistance normalised by the overburden pressures. Bo et al. (1998b) have proposed the following correlation with OCR (Figure 13) and normalised corrected cone resistance

17. $\mathrm{OCR}=\alpha\left(q_{\mathrm{t}}-\sigma_{\mathrm{vo}}\right) / \sigma_{\mathrm{vo}}^{\prime}$

where $\alpha$ is a constant and has a value of 0.32 for the Singapore marine clay at Changi.

The correlations above are obtained by applying regression analyses on a large database for the Changi site using cone resistance data and OCR values interpreted from oedometer tests carried out on the samples collected at the same location and same depths from the boreholes. 
Research-oriented ground investigation

projects at Changi, Singapore

Bo, Arulrajah, Choa, Horpibulsuk and Samingthong

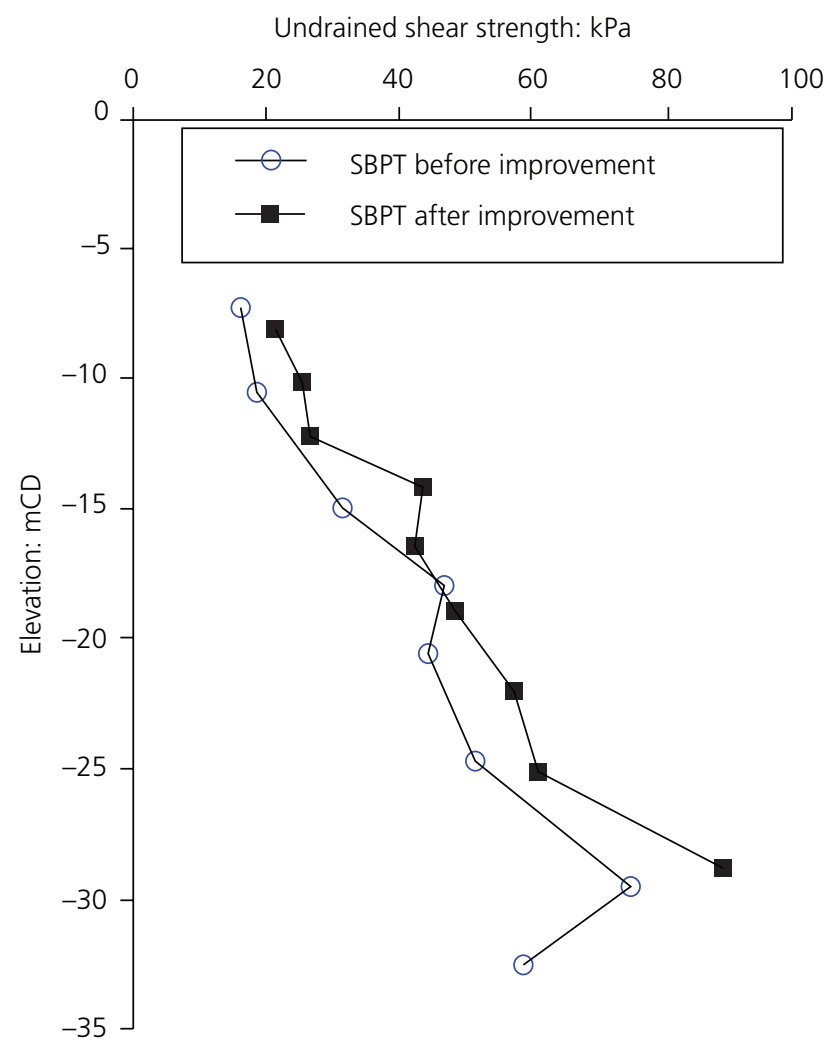

Figure 12. Comparison of parameters measured by the SBPT prior to and after improvement (Bo and Choa, 2004)

Correlation of dilatometer lateral stress index with OCR From the lateral stress index $K_{\mathrm{D}}$, the OCR of clay can be estimated as proposed by Marchetti (1980)

18. $\mathrm{OCR}=0 \cdot 5 K_{\mathrm{D}}^{1 \cdot 56}$

Bo et al. (1998a) proposed the power function 1.0 for lower and upper Singapore marine clay and 0.8 for intermediate Singapore marine clay instead of $1 \cdot 56$. Figure 14 also shows OCR estimated from the DMT.

\section{Correlation of total horizontal stress measured from} SBPIM with OCR

Since the self-boring pressuremeter can measure the total horizontal stress, it is possible to determine the $K_{0}$ values; hence, OCR can be estimated. Figure 13 also shows the OCR interpreted from the selfboring pressuremeter compared with laboratory results.

19. $\mathrm{OCR}=\left(\frac{K_{0 \mathrm{oc}}}{K_{0 \mathrm{nc}}}\right)^{1 / h}$

where $h=0 \cdot 32-0 \cdot 40$.

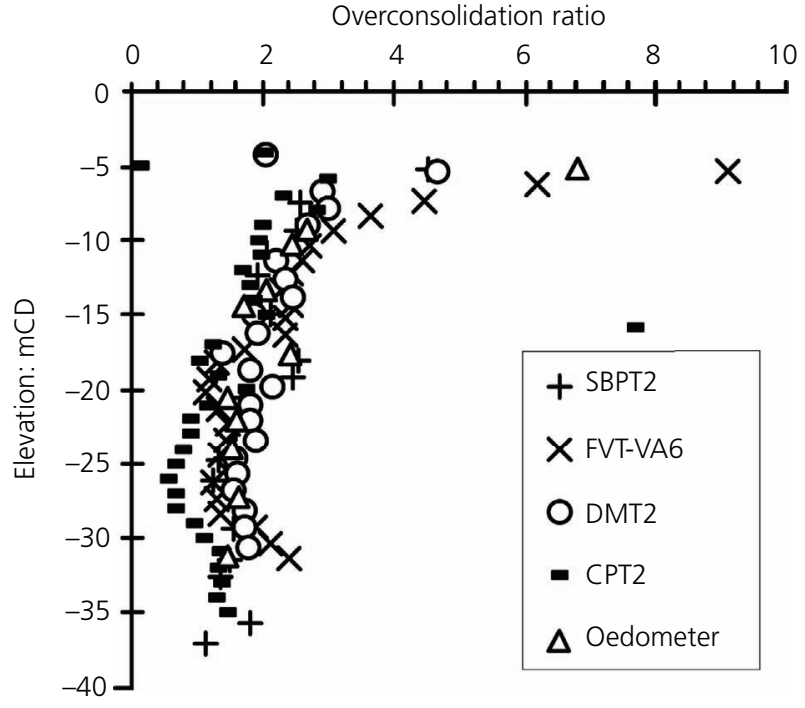

Figure 13. Overconsolidation ratio interpreted from specialised in situ tests (Bo and Choa, 2004)

\section{Correlation of ram sounding blow counts with SPT}

During a series of tests in the loose and dense granular fills, correlation was established between Swedish RST and SPT blow counts for 20 and $30 \mathrm{~cm}$, respectively. This correlation was obtained by applying regression analyses using data from SPT and RSTs which were carried out side-by-side at a reclaimed area at Changi. After successfully obtaining and validating this correlation, ram sounding was used as an alternative tool for performance verification of the densification works on reclaimed fills.

20. $N_{\mathrm{RST}}=0 \cdot 5 N_{\mathrm{SPT}}$

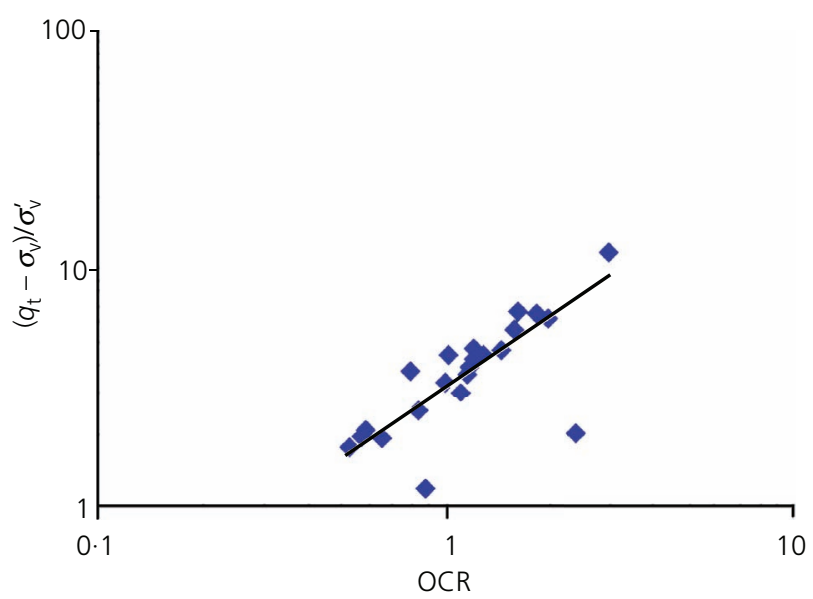

Figure 14. Correlation between cone resistance and OCR 


\section{Conclusions}

This paper presents how the research-oriented Changi East Reclamation and Ground Improvement projects were planned and implemented for this enormous land reclamation project in the Republic of Singapore. An accurate and extensive geotechnical characterisation of underlying soft compressible marine clay was undertaken as part of this project. The geotechnical characterisation was undertaken using site investigation, specialised laboratory testing and specialised in situ testing techniques.

The elevations of the top and base as well as the thicknesses of the compressible layers and the distribution and dimensions of soft marine clay pockets deposited in submarine valley cuts were determined from marine hydrographic and seismic reflection surveys and geotechnical site investigations.

Photographic identifications and XRD and electron microscope analyses were carried out to identify the mineralogy of the Singapore marine clay. Photographic identification was found to enable the characterisation of the colours, textures and laminations of the Singapore marine clay, as well as depths of the sand seams, organic material and layers of past exposure to oxidation.

In addition to conventional boring, sampling and FVTs and SPTs, specialised in situ tests such as CPTU, DMT, SBPM, CPMT, SCT, PLT, SPLT, auto ram sounding and gamma-gamma probe tests were carried out. In addition to conventional UU strength tests, many other specialised tests such as CIU, CID, $\mathrm{C} K_{0} \mathrm{U}$, $\mathrm{C} K_{0} \mathrm{D}$, direct shear tests, Shansep and stress path and strain path tests were carried out in order to study the mode of failure-dependent strength characteristics of Singapore marine clay in Changi. Correlations were established for the stress history, undrained shear strength and normalised soil engineering properties of the Singapore marine clay in Changi from in situ tests as well as from laboratory tests. Correlations were also established between Swedish ram sounding equipment and SPTs.

In addition to the conventional oedometer tests, various types of consolidation tests such as CRS, CRL, EOP and Rowe cell tests with various combinations of strain rates, loading rates and drainage condition were carried out to study the stress-, strain- and drainagedependent consolidation behaviours of Singapore marine clay in Changi. Empirical correlations have been proposed for relationships between classification parameters as well as compressibility parameters for the marine clay in Changi, Singapore.

The properties and correlations developed for the Singapore marine clay at Changi in this paper will be useful to researchers and practising engineers involved in land reclamation and ground improvement projects on soft marine clay formations.

\section{Acknowledgements}

The fourth and last authors are grateful to the Thailand Research Fund under the TRF Senior Research Scholar programme grant RTA5980005 and Suranaree University of Technology.

\section{REFERENCES}

Aas G, Lacasse S, Lunne T and Hoeg K (1986) Use of in-situ tests for foundation design on clay. Proceedings of 14th ASCE Specialty Conference on Use of In-situ Tests in Geotechnical Engineering, Blacksburg, VA, USA, pp. 1-30.

Arulrajah A, Bo MW and Nikraz H (2004a) Characterization of soft marine clay using the flat dilatometer. Proceedings of the 2 nd International Conference on International Site Characterization, Porto, Portugal, pp. 287-292.

Arulrajah A, Bo MW and Nikraz H (2004b) Pre-reclamation characteristics of marine slay using in-situ testing methods. Proceedings of the 2nd International Conference on International Site Characterization, Porto, Portugal, pp. 1041-1046.

Arulrajah A, Nikraz H and Bo MW (2005) In-situ testing of Singapore marine clay at Changi. Geotechnical and Geological Engineering 23(2): 111-130, http://dx.doi.org/10.1007/s10706-003-7329-0.

Arulrajah A, Nikraz H, Bo MW and Hashim R (2006a) In-situ pore water pressure dissipation testing of marine clay under reclamation fills. Geotechnical and Geological Engineering 24(1): 29-43, http://dx.doi.org/10.1007/s10706-004-1807-x.

Arulrajah A, Bo MW, Nikraz H and Hashim R (2006b) Pre-reclamation in-situ testing of soft soil. Australian Geomechanics 41(4): 57-68.

Arulrajah A, Bo MW, Nikraz H and Balasubramaniam AS (2007) Dissipation testing of Singapore marine clay by piezocone tests. Geotechnical and Geological Engineering 25(6): 647-656, http://dx.doi.org/10.1007/s10706-007-9137-4.

Arulrajah A, Bo MW and Nikraz H (2009) In-situ dissipation testing of soft soil under reclamation fills. Australian Geomechanics 44(1): 69-79.

Arulrajah A, Bo MW, Piratheepan J and Disfani MM (2011) In-situ testing of soft soil at a case study site with the self-boring pressuremeter. ASTM Geotechnical Testing Journal 34(4): 1-9, http://dx.doi.org/10. 1520/GTJ103310.

Atkinson JH, Evans JS and Ho EWL (1985) Non-uniformity of triaxial samples due to consolidation with radial drainage. Géotechnique 35(3): 353-356, http://dx.doi.org/10.1680/geot.1986.36.4.611.

Bo MW and Choa V (2004) Reclamation and Ground Improvement. Cengage Learning, Singapore.

Bo MW, Arulrajah A and Choa V (1998a) The hydraulic conductivity of Singapore marine clay at Changi. Quarterly Journal of Engineering Geology 31(4-2): 291-299.

Bo MW, Arulrajah A, Choa V and Chang MF (1998b) Site characterization for a land reclamation project at Changi in Singapore. In 1st International Conference on Site Characterization (Geotechnical Site Characterization) (Robertson PK and Mayne PW (eds)). Balkema, Leiden, the Netherlands, pp. 333-340.

Bo MW, Cao LF, Chu J and Choa V (1998c) One-dimensional consolidation tests on Singapore marine clay at Changi. Proceedings of the 13th Southeast Asian Geotechnical Conference, Taipei, Taiwan, pp. 199-206.

Bo MW, Chang MF, Arulrajah A and Choa V (2000) Undrained shear strength of the Singapore marine clay at Changi from in-situ tests. Geotechnical Engineering Journal of the Southeast Asian Geotechnical Society 31(2): 91-107.

Bo MW, Chu J and Choa V (2001) Comparison of consolidation parameters measured by laboratory and in-situ tests. Proceedings of the 15th International Conference on Soil Mechanics and Geotechnical Engineering, Istanbul, Turkey.

Bo MW, Choa V and Hong KH (2003) Material characterization of Singapore marine clay at Changi. Quarterly Journal of Engineering Geology and Hydrogeology 36(4): 305-319, http://dx.doi.org/10.1144/ 1470-9236/03-009.

Bo MW, Choa V and Wong KS (2008) Constant rate of displacement test on ultra-soft soils. Proceedings of the Institution of Civil Engineers Geotechnical Engineering 161(3): 129-135, http://dx.doi.org/10.1680/ geng.2008.161.3.129. 
Research-oriented ground investigation

projects at Changi, Singapore

Bo, Arulrajah, Choa, Horpibulsuk and Samingthong
Bo MW, Choa V and Wong KS (2009) Discussion on constant rate of displacement test on ultra-soft soils. Proceedings of the Institution of Civil Engineers - Geotechnical Engineering 162(6): 347-348, http://dx.doi. org/10.1680/geng.2009.162.6.347.

Bo MW, Choa V and Wong KS (2010) Constant rate of loading test on ultra-soft soil. Geotechnical Testing Journal 33(3): 192-200, http://dx.doi.org/10.1520/GTJ102802.

Bo MW, Chang MF, Arulrajah A and Choa V (2012) Ground investigations for Changi East Reclamation projects. Geotechnical and Geological Engineering 30(1): 45-62, http://dx.doi.org/10.1007/ s10706-011-9448-3.

Bo MW, Arulrajah A, Leong M, Horpibulsuk S and Disfani MM (2014) Evaluating the in-situ hydraulic conductivity of soft soil under land reclamation fills with the BAT permeameter. Engineering Geology 168: 98-103, http://dx.doi.org/10.1016/j.enggeo.2013.11.001.

Bo MW, Arulrajah A, Sukmak P and Horpibulsuk S (2015a) Mineralogy and geotechnical properties of Singapore marine clay at Changi. Soils and Foundations 55(3): 600-613, http://dx.doi.org/10.1016/ j.sandf.2015.04.011.

Bo MW, Arulrajah A, Sukmak P, Horpibulsuk S and Leong M (2015b) Mineralogy and geotechnical properties of ultra-soft soil from a nearshore mine tailings sedimentation pond. Marine Georesources and Geotechnology 34(8): 782-791, http://dx.doi.org/10.1080/ 1064119X.2015.1094158.

Bo MW, Choa V, Chu J, Arulrajah A and Horpibulsuk S (2016) Laboratory investigation on the compressibility of Singapore marine clays. Marine Georesources and Geotechnology, http://dx.doi.org/10.1080/1064119X. 2016.1256922 .

Chang MF (1991) Flat dilatometer tests in clay deposits of Singapore. Proceedings of the 9th Asian Regional Conference on Soil Mechanics and Foundation Engineering, Bangkok, Thailand, vol. 1, pp. 23-28.

Chang MF, Choa V, Cao LF and Bo MW (1997) Overconsolidation ratio of a seabed clay from in-situ test. Proceedings of the 14th International Conference on Soils Mechanics and Foundation Engineering, Hamburg, Germany, pp. 453-456.

Chang MF, Choa V and Bo MW (1998) Use of in-situ tests in land reclamation projects in Singapore. Proceedings of the 13th Southeast Asian Geotechnical Conference, Taipei, Taiwan, pp. 16-20.

Chang MF, Bo MW, Choa V and Teh Cl (2001) Evaluation of shear strength parameters of Singapore marine clay. Proceedings of Singapore Underground 2001, Singapore, pp. 29-30.

Cao LF (1997) Interpretation of In-Situ Tests in Clay with Particular Reference to Reclaimed Sites. PhD thesis, Nanyang Technological University, Singapore.

Cao LF, Chang MF and Teh Cl (1996) Cavity Expansion Modified Cam Clay and Its Application to the Interpretation of Piezocone Tests. Nanyang Technological University, Singapore, Geotechnical Research Report NTU/GT 96-03.

Cao LF, Na YM, Bo MW and Choa V (1998) Analysis of cone pressuremeter test in clay. Proceedings of the 13th Southeast Asian Geotechnical Conference, Taipei, Taiwan, pp. 23-28.
Choa V, Chu J, Bawajee R, Bo MW and Arulrajah A (1996) The strength and consolidation behaviour of Singapore marine clay at Changi. Proceedings of the 12th Southeast Asian Geotechnical Conference, Kuala Lumpur, Malaysia, pp. 81-85.

Chu J, Choa V and Bo MW (1999) Determination of undrained shear strength of clay by direct simple shear tests. In 11th Asian Regional Conference on Soil Mechanics and Geotechnical Engineering (Hong SW (ed.)). Balkema, Rotterdam, the Netherlands, pp. 49-52. Chu J, Bo MW, Chang MF and Choa V (2002) The consolidation and permeability properties of Singapore marine clay. Geotechnical and Geoenvironmental Engineering Journal 128(9): 724-732, http://dx.doi.org/10.1061/(ASCE)1090-0241(2002)128:9(724).

Chu J, Bo MW, Chang MF and Choa V (2004) Closure to the consolidation and permeability properties of Singapore marine clay. Geotechnical and Geoenvironmental Engineering Journal 128(9): 339-340, http://dx.doi.org/10.1061/(ASCE)1090-0241(2004)130:3(340).

Chu J, Bo MW and Arulrajah A (2009) Soil improvement works for an offshore land reclamation. Proceedings of the Institution of Civil Engineers - Geotechnical Engineering 162(1): 21-32, http://dx.doi. org/10.1680/geng.2009.162.1.21.

De Ruiter J (1982) The static cone penetration test: state-of-the-art report. Proceedings of the 2nd European Symposium on Penetration Testing, Amsterdam, the Netherlands, pp. 389-405.

Houlsby GT and Nageswaran S (1982) A study of consolidation with radial drainage. Proceedings of the Critical State Soil Mechanics Workshop, Cambridge, UK.

Ladd CC, Foott R, Ishihara K, Schlosser F and Poulos HG (1977) Stress deformation and strength characteristics state of the art report. Proceedings of the 9th International Conference on Soil Mechanics and Foundation Engineering, Tokyo, Japan, vol. 2, pp. 421-494.

Lunne T, Eide O and de Ruiter J (1976) Correlations between cone resistance and vane shear strength in some Scandivanian soft to medium stiff clays. Canadian Geotechnical Journal 13(4): 430-441.

Marchetti S (1980) In-situ tests by flat dilatometer. Journal of Geotechnical Engineering Division 106(GT3): 299-321.

Marsland A and Randolph MF (1977) Comparison of the results from pressuremeter tests and large in-situ plate tests in London clay. Géotechnique 27(2): 217-243, http://dx.doi.org/10.1680/geot.1977.27. 2.217 .

Mayne PW and Bachus RC (1988) Profiling OCR in clays by piezocone soundings. In Penetration Testing 1988 (ISOPT-1) (De Ruiter J (ed.)). Balkema, Rotterdam, the Netherlands, vol. 2, pp. 857-864.

Na YM, Choa V, Chang MF, Teh Cl and Bo MW (1999) Estimation of geotechnical parameters of granular soils from various in-situ tests. In 11th Asian Regional Conference on Soil Mechanics and Geotechnical Engineering (Hong SW (ed.)). Balkema, Rotterdam, the Netherlands, pp. $277-280$.

Sugawara N (1988) On the possibility of estimating in-situ OCR using piezocone (CUPT). In Penetration Testing 1988 (ISOPT-1) (De Ruiter J (ed.)). Balkema, Rotterdam, the Netherlands, vol. 2, pp. 985-991.

Terzaghi K and Peck RB (1967) Soil Mechanics in Engineering Practice, 2nd edn. Wiley, Hoboken, NJ, USA.

\section{How can you contribute?}

To discuss this paper, please submit up to 500 words to the editor at journals@ice.org.uk. Your contribution will be forwarded to the author(s) for a reply and, if considered appropriate by the editorial board, it will be published as a discussion in a future issue of the journal. 